\title{
Comparison of liquid hot water, very dilute acid and alkali treatments for enhancing enzymatic digestibility of hazelnut tree pruning residues
}

\author{
Kevser Sabanci, Ali Oguz Buyukkileci* \\ Department of Food Engineering, Faculty of Engineering, Izmir Institute of Technology, 35430 Gulbahce, Urla, Izmir, Turkey
}

\section{A R T I C L E I N F O}

\section{Keywords:}

Hazelnut tree pruning residue

Lignocellulosic biomass valorization

Pretreatment

Saccharification

\begin{abstract}
A B S T R A C T
The effect of pretreatments on the composition of the hazelnut tree pruning residue (HTPR) and on the digestibility of the cellulose was investigated. The liquid hot water (LHW) and the very dilute acid (VDA) treatments were effective in solubilizing hemicellulose. The cellulose conversion increased up to around 60\% (corresponding to $32-36 \mathrm{~g} / \mathrm{L}$ glucose) with decreasing hemicellulose concentration in the pretreated HTPR. The alkali treatment provided partial delignification, however, the glucose production was comparably lower. Combining the hemicellulose removal and the delignification effect of different pretreatments in two-stage processes (LHW-alkali and VDA-alkali treatments) enhanced the cellulose concentration in the solids, but not the amount of glucose released in the enzymatic digestion. These results suggested that the hemicellulose was the main barrier against the conversion of cellulose in the LHW and VDA treated HTPR and the glucose in the hydrolysis medium inhibited the cellulase activity, which prevented the complete conversion of cellulose.
\end{abstract}

\section{Introduction}

Lignocellulosic materials are composed mainly of cellulose, hemicellulose, and lignin and they are recognized as a sustainable feedstock for the production of bio-based chemicals, such as pharmaceuticals, fine chemicals, bulk chemicals and fuels (Fiorentino et al., 2017). However, lignocellulosic materials are recalcitrant and they resist to enzymatic saccharification in their native form. Therefore, pretreatments are required to render the cellulose amenable to enzymatic hydrolysis. Hemicellulose and lignin parts of the lignocellulosic biomass have been generally considered as physical barriers that restrict the accessibility of cellulose by cellulolytic enzymes.

Several physical, chemical, physicochemical and biological pretreatment methods are available for disrupting the rigid lignocellulosic network. Liquid hot water (LHW) treatment (also known as autohydrolysis, hot compressed water, and subcritical water treatment), which is carried out in pressure reactors using subcritical water, draws attention since it does not require any catalyst and corrosion resistant reactors and it releases relatively lower amount of sugar degradation products (Alvira et al., 2010). In LHW treatment, water auto-ionizes and the acetyl groups on the hemicellulose are released as acetic acid; both provide hydronium ions for the hydrolysis reactions between hemicellulose and lignin and within the carbohydrates (Heitz et al., 1986). LHW has been demonstrated to be a successful method to remove part of the hemicellulose in several lignocellulosic materials, including sugar cane bagasse (Laser et al., 2002), corn stover (Mosier et al., 2005), wheat straw (Pérez et al., 2008), and sunflower stalks (Monlau et al., 2012). Concentrated acids can hydrolyze cellulose directly, however, they are corrosive and hazardous. Dilute acid (DA) treatment at elevated temperatures, on the other hand, targets hemicellulosic carbohydrates allowing removal and hydrolysis of those. This releases hemicellulosic monomers, such as xylose, mannose, and arabinose, and facilitate enzymatic hydrolysis of cellulose (Sun and Cheng, 2002). DA treatment generally carried out using $0.5-5 \%$ sulphuric acid (or other acids) at temperatures of $121-220^{\circ} \mathrm{C}$ (Lee et al., 2015a; Sun and Cheng, 2002). This treatment suffers from carbohydrate degradation and consequent inhibitor formation (Zabed et al., 2016). The other well-established method is the alkali pretreatment. Under alkaline conditions, the ester linkages in hemicellulose and lignin are easily broken. This significantly promotes the solubilization of hemicelluloses and lignin, and increases porosity and surface area, resulting in the exposure of cellulose to enzymes (Kim et al., 2016; Zheng et al., 2009). Unlike acid-based treatments, sugar degradation does not occur in alkali treatment (Zabed et al., 2016).

Following the pretreatment processes, the lignocellulosic materials are subjected to enzymatic hydrolysis for saccharification. The conditions of the pretreatment process, such as temperature, time and catalyst concentration as well as of the enzymatic hydrolysis should be optimized to ensure maximum cellulose conversion. An effective pretreatment is necessary to achieve an efficient enzymatic

\footnotetext{
* Corresponding author.

E-mail address: oguzbuyukkileci@iyte.edu.tr (A.O. Buyukkileci).
} 
saccharification.

Hazelnut (Corylus avellana L.) is one of the main agricultural products in Turkey with an annual production of 420,000 tons, accounting for $56 \%$ of the total production worldwide (FAOSTAT, 2016). During hazelnut agriculture and processing, high amount of lignocellulosic biomass, in the form of shell, skin, husk, leaves, and woody biomass is discarded. The residues of hazelnut production have no economic value; i.e., they are usually burned in fields or in heaters and not utilized for production of value-added chemicals and materials (Çöpür et al., 2013). The potential of hazelnut residues has been shown in some research reports. Hazelnut shell, skin, husk, and leave were reported to contain compounds with antioxidant activity (Esposito et al., 2017; Shahidi et al., 2007; Surek and Buyukkileci, 2018). Çöpür et al. (2013) treated the steam-exploded husks with $\mathrm{NaOH}, \mathrm{H}_{2} \mathrm{SO}_{4}, \mathrm{H}_{2} \mathrm{O}_{2}$ or $\mathrm{NaBH}_{4}$, and obtained $52.6 \mathrm{~g}$ ethanol per kg husks. Surek and Buyukkileci (2017) recovered $62 \%$ of the xylan in the shell in the form of xylooligosaccharides using autohydrolysis treatment. Colantoni et al. (2015) showed that hazelnut prunings could be used to produce biochar.

The amount of hazelnut tree pruning residue (HTPR) in Turkey was reported to be over 2 million tons per year (Bascetincelik et al., 2006). It contains a substantial amount of polysaccharides, thus it can be considered as a potential source of fermentable carbohydrates (Surek and Buyukkileci, 2017). In this study, the potential of HTPR was tested through pretreatments followed by enzymatic hydrolysis of cellulose into glucose. It was treated for the first time with LHW, very dilute acid (VDA), and alkali solutions under various conditions. All of the LHW and VDA treated HTPR samples and one of the alkali treated HTPR samples were then subjected to hydrolysis using a commercial cellulase. Although the pretreatments applied are well-known and have been tested on various lignocellulosic biomass, their effect on the particular biomass could be different and the optimization of the operational

reaction time ( $15 \mathrm{~min}$ or $45 \mathrm{~min}$ ), the reactor was cooled to $60{ }^{\circ} \mathrm{C}$ within 20-25 min with tap water circulating in the cooling coil. The liquid and solid phases were separated by filtration through Whatman No.1 filter under vacuum. The solid phase was washed repeatedly with distilled water until the $\mathrm{pH}$ of the water after the rinsing was almost neutral. After drying at $60^{\circ} \mathrm{C}$ until constant weight, the solid recovery was measured gravimetrically.

In the DA treatment, HTPR was treated with $0.1 \% \mathrm{H}_{2} \mathrm{SO}_{4}(\mathrm{w} / \mathrm{v})$ at $130^{\circ} \mathrm{C}, 150^{\circ} \mathrm{C}, 170^{\circ} \mathrm{C}$, and $190^{\circ} \mathrm{C}$ for $15 \mathrm{~min}$ in the pressure reactor. The solid-liquid ratio, reactor operating conditions, and processing of the treated solids were the same as described for the LHW treatment. Due to the relatively low concentration of the $\mathrm{H}_{2} \mathrm{SO}_{4}$, the process was called "very dilute acid (VDA) treatment" in this study.

The alkali treatment of HTPR was performed at $121{ }^{\circ} \mathrm{C}$ for $60 \mathrm{~min}$ in an autoclave, at a solid-liquid ratio of $1: 10$, using $0 \%, 0.5 \%$ and $2 \%$ $\mathrm{NaOH}$ solution. The treated biomass was processed as described for LHW treated solids. In two-stage treatments, the LHW and the VDA treated HTPR samples were subjected to alkali treatment as described above.

For each treatment, solid recovery (Eq. (1)) and the fraction of cellulose recovered in the pretreated HTPR (Eq. (2)) were calculated. Similarly, the hemicellulose and lignin removed from the HTPR in the treatments were calculated (Eq. (3)). All calculations were done on a dry weight basis.

Solid recovery $(\%)=\frac{\text { Amount of insoluble solid after pretreatment }(\mathrm{g})}{\text { Initial amount of biomass before pretreatment }(\mathrm{g})} \times 100$

Cellulose recovery $(\%)=\frac{\text { Amount of cellulose in the pretreated biomass }(\mathrm{g})}{\text { Amount of cellulose in the raw material }(\mathrm{g})} \times 100$

Hemicellulose/Lignin removal $(\%)=\frac{\text { Hemicellulose/Lignin in the raw material }(\mathrm{g})-\text { Hemicellulose/Lignin in the treated solid }}{\text { Hemicellulose/Lignin in the raw material(g) }} \times 100$

conditions is needed. The removal of hemicellulose and lignin from the lignocellulosic network can potentially increase the enzymatic digestibility of cellulose. Therefore, the extent of hemicellulose and lignin removal in the pretreatments were measured and their effects on cellulose digestibility were quantified. Alternatively, pretreatment was applied in two stages (LHW-alkali or VDA-alkali) in order to combine the effects of different treatments.

\section{Materials and methods}

\subsection{Materials}

The HTPR, which was composed of thick branches with a diameter of 1.5-3.0 cm, was obtained from hazelnut producers in Ordu, Turkey. The HTPR was dried in an oven at $60{ }^{\circ} \mathrm{C}$ for two days and milled to a particle size less than $2 \mathrm{~mm}$. The dry samples stored at room temperature until use.

All chemicals were of analytical grade and purchased from SigmaAldrich (Steinheim, Germany) and Merck Millipore (Darmstadt, Germany). The cellulase (Accellerase 1500) and the $\beta$-glucosidase (Accelerase BG) enzymes were kind gifts from DuPont, Finland.

\subsection{Pretreatments}

The LHW treatment was carried out in duplicates in the pressure reactor (BR-300, Berghof, Eningen, Germany). The biomass ( $25 \mathrm{~g}$ ) was mixed with deionized water $(250 \mathrm{~mL})$ in the stainless-steel tank with a $600 \mathrm{~mL}$ total volume and the mixture was heated to $170{ }^{\circ} \mathrm{C}, 190^{\circ} \mathrm{C}$, and $210^{\circ} \mathrm{C}$ by the surrounding heating block. The content was continuously stirred with the paddle agitator rotating at $300 \mathrm{rpm}$. At the end of the

\subsection{Enzyme assays}

The cellulase activity in Accellerase 1500 was determined by measuring the released glucose after incubation of the enzyme solution and the substrate for a certain time (Adney and Baker, 2008). Filter-paper strip $(1.0 \times 6.0 \mathrm{~cm})$ in $1.0 \mathrm{~mL} 50 \mathrm{mM}$ sodium citrate buffer $(\mathrm{pH} 4.8)$ was incubated with $0.5 \mathrm{~mL}$ enzyme solution at $50{ }^{\circ} \mathrm{C}$ for $60 \mathrm{~min}$ in a water bath. The reaction was stopped by the addition of $3.0 \mathrm{~mL}$ of DNS reagent and the absorbance of the solution was read at $540 \mathrm{~nm}$. One filter paper unit (FPU) of enzyme activity was defined as the amount of enzyme that released $1 \mu \mathrm{mol}$ of reducing sugar in $1 \mathrm{~min}$ at $50^{\circ} \mathrm{C}$ and $\mathrm{pH}$ 4.8.

The $\beta$-glucosidase activity in Accelerase BG and Accellerase 1500 was determined according to Grover et al. (1977) using p-nitrophenyl$\beta$-D-glucopyranoside (pNPG) as the substrate. The enzyme solution $(500 \mu \mathrm{L})$ was mixed with $1000 \mu \mathrm{L} 6.67 \mathrm{mM}$ pNPG in acetate buffer (133 mM, pH 4.8) and the mixture was incubated at $50^{\circ} \mathrm{C}$ for $30 \mathrm{~min}$ in a water bath. The reaction was stopped by $2 \mathrm{~mL}$ of $200 \mathrm{mM} \mathrm{Na}_{2} \mathrm{CO}_{3}$ and the absorbance of the solution was measured at $400 \mathrm{~nm}$. One unit of $\beta$ glucosidase activity was defined as the amount of enzyme which produced $1 \mu \mathrm{mol}$ of p-nitrophenol in $1 \mathrm{~min}$ at $50{ }^{\circ} \mathrm{C}$ and $\mathrm{pH} 4.8$. The activity was calculated by taking the p-NPG extinction coefficient as $18.1 \mathrm{~cm}^{2}$ / $\mu \mathrm{mol}$.

\subsection{Enzymatic saccharification}

Saccharification of the pretreated HTPR was carried out in duplicates as described by Selig et al. (2009) except that higher solid loading 
was used. In $25 \mathrm{~mL}$ Erlenmeyer flasks, $1 \mathrm{~g}$ of pretreated HTPR was suspended in $10 \mathrm{~mL}$ of $50 \mathrm{mM}$ sodium citrate buffer ( $\mathrm{pH} 4.8$ ), corresponding to a solid-liquid ratio of $1: 10$. In order to prevent microbial contamination, $100 \mu \mathrm{L}$ of sodium azide solution $(2 \% \mathrm{w} / \mathrm{v})$ was added. The cellulase dosage was 15,30 and $60 \mathrm{FPU} / \mathrm{g}$ biomass, while the $\beta$ glucosidase was used at $40 \mathrm{U} / \mathrm{g}$ biomass. The flasks were incubated in an orbital shaker (Zhicheng, China) at $150 \mathrm{rpm}$ at $50^{\circ} \mathrm{C}$ for $72 \mathrm{~h}$. The samples were taken from the reaction mixture at intervals $(0,24,48$, and $72 \mathrm{~h}$ ) and the enzymatic activity was stopped by keeping the tubes in a boiling water bath for $10 \mathrm{~min}$. The hydrolysates were clarified by centrifugation at $5000 \mathrm{rpm}$ for $5 \mathrm{~min}$. The glucose concentrations in the supernatants was measured by HPLC. All enzymatic hydrolysis experiments were performed in duplicates, and the average results were reported. Enzymatic digestibility was reported as percent cellulose conversion to glucose (Eq. (4)) and global glucose yields were calculated based on the dry weight of raw HTPR (Eq. (5)).

Cellulose conversion $(\%)=\frac{\text { Glucose released }(\mathrm{g}) \times \text { Anhydrous factor }(0.9)}{\text { Cellulose in pretreated solid }(\mathrm{g})} \times 100$

Glucose yield $(\%)=\frac{\text { Glucose released }(\mathrm{g})}{\text { Amount of raw material before pretreatment }(\mathrm{g})} \times 100$

\subsection{Analytical methods}

\subsubsection{Structural carbohydrates and lignin analysis}

Cellulose, hemicellulose and lignin concentrations of raw and pretreated HTPR were determined according to Sluiter et al. (2011). The biomass samples ( $300 \mathrm{mg}$ ) were treated with $3 \mathrm{~mL}$ of $72 \%(\mathrm{w} / \mathrm{w}) \mathrm{H}_{2} \mathrm{SO}_{4}$ for $60 \mathrm{~min}$ and diluted to $4 \%$ by adding $84 \mathrm{~mL}$ water. The diluted solution was kept at $121^{\circ} \mathrm{C}$ for $60 \mathrm{~min}$ in an autoclave. The $\mathrm{pH}$ was increased to 5-7 using $\mathrm{CaCO}_{3}$ and the samples were centrifuged to remove insoluble particles. Acid hydrolysis disintegrates cellulose and hemicellulose in the lignocellulosic biomass into corresponding monomers. The monomer concentrations in the hydrolysates were determined by HPLC and the cellulose and hemicellulose concentrations were calculated by multiplying the monomer concentrations by anhydrous factors ( 0.90 for glucose and 0.88 for xylose, arabinose, and galactose). The acid soluble lignin in the hydrolysate was determined spectrophotometrically at $240 \mathrm{~nm}$ using an absorptivity value of $25 \mathrm{~L} / \mathrm{g}$ $\mathrm{cm}$. The insoluble solid after the acid hydrolysis was filtered through porcelain filter crucibles under vacuum and dried at $105^{\circ} \mathrm{C}$. The weight of this solid is reported as the Klason lignin. The ash content of the HTPR was reported to be low $(<1.0 \% \mathrm{w} / \mathrm{w})$ (Surek and Buyukkileci, 2017), therefore it was not taken into account in the gravimetric lignin analysis.

\subsubsection{Carbohydrate analysis}

Glucose, xylose, arabinose, and galactose concentrations were measured using HPLC (Perkin Elmer Series 200, Waltham, MA). The samples were clarified by centrifugation and filtration through $0.45 \mu \mathrm{m}$ cellulose-acetate membrane filters. The analyses were carried out using a Rezex RPM-Monosaccharide column (Phenomenex, Torrance, CA) at $80^{\circ} \mathrm{C}$ and a refractive index (RI) detector. Ultra-pure water at a flow rate of $0.6 \mathrm{~mL} / \mathrm{min}$ was used as the mobile phase. The concentrations of the monosaccharides were calculated by comparing the peak areas in the chromatograms to the respective calibration curves.

All of the results are reported on a dry weight basis.

\section{Results and discussion}

\subsection{Characterization of hazelnut tree pruning residues}

The lignocellulosic composition of the HTPR was determined in order to assess the potential of this biomass as a feedstock for bioproduction processes and calculate the efficiency of the pretreatment and enzymatic hydrolysis operations. The HTPR had $10 \%$ moisture as received. The dominant component in the dried biomass was cellulose (37.2\%), followed by lignin (28.5\% insoluble and $2.5 \%$ acid soluble). The hemicellulosic part was composed of xylan (16.5\%), galactan (1.89\%), and arabinan (2.06\%). In total, the lignocellulosic part accounted for the $86.1 \%$ of the HTPR. In a previous study of our group, the HTPR was found to contain $2.0 \%$ acetyl groups as substitutions on xylan, $4.0 \%$ extractives, and $4.5 \%$ protein (Surek and Buyukkileci, 2017). The cellulose content of the HTPR was slightly lower than the values reported for other hardwoods, while hemicellulose and lignin contents were comparable (Alvarez et al., 2016).

\subsection{Pretreatment of hazelnut tree pruning residues}

The HTPR was treated with LHW at elevated temperatures $\left(170-210^{\circ} \mathrm{C}\right)$, which have been required for effective hemicellulose solubilization (Zabed et al., 2016). The VDA was applied at slightly lower temperatures $\left(130-190^{\circ} \mathrm{C}\right)$ according to the previous reports (Zabed et al., 2016; Loow et al., 2016) and the preliminary experiments. The alkali treatment was carried out at a relatively lower temperature $\left(121^{\circ} \mathrm{C}\right)$ and for a longer time $(60 \mathrm{~min})$, which is a characteristic of alkaline based treatments (Taherzadeh and Karimi, 2008). The $\mathrm{NaOH}$ concentration range was selected according to the preliminary experiments. In an effort to increase further the efficiency of the pretreatment step, LHW and VDA treatments were followed by alkali treatment, which processes were called as "the two-stage pretreatments".

The LHW treatment has been known to be effective on solubilization and partial hydrolysis of the hemicellulosic carbohydrates (Jonsson and Martin, 2016). The solubilization of the hemicellulose of the HTPR increased with increasing temperature or time of the LHW treatment (Table 1). The HTPR treated at $210^{\circ} \mathrm{C}$ were almost free of hemicellulose. Galactan and arabinan portions of the hemicellulose were solubilized under all conditions, thus xylan was the sole hemicellulosic carbohydrate in the pretreated HTPR, if any. The cellulose was retained in the pretreated HTPR to a great extent (Table 1). The LHW treatments at $190{ }^{\circ} \mathrm{C}$ and $210^{\circ} \mathrm{C}$ increased the cellulose fraction slightly over $50 \%$ from the initial value of $37.2 \%$. The lignin amount was measured to be up to $18.6 \%$ higher than the one in the raw (untreated) HTPR (Table 1). This phenomenon has been reported previously for LHW and DA treatments and was linked to the formation of lignin-like materials (pseudo-lignin) (Carvalheiro, 2004; Hu and Ragauskas, 2014; Ma et al., 2015). These could be originated from the condensation of sugar degradation products, such as hydroxy-methyl furfural, and furfural $\mathrm{Hu}$ and Ragauskas, 2014). In this study, lignin deposition peaked in the treatment at $190{ }^{\circ} \mathrm{C}$ for $45 \mathrm{~min}$ and was pronounced less in treatments at $210^{\circ} \mathrm{C}$. The LHW treatments of HTPR at $190{ }^{\circ} \mathrm{C}$ and $210{ }^{\circ} \mathrm{C}$ solubilized almost one-third of the solids and yielded biomass composed approximately of half cellulose and half lignin, containing an only a small amount of xylan. In several previous studies, LHW provided a treated biomass that was free from hemicellulose and contained more than $50 \%$ cellulose, for example from giant reed (Jiang et al., 2016), wheat straw (Pérez et al., 2008), and vine pruning residues (Jesus et al., 2017). Similar to the LHW treatment, hemicellulose removal from the HTPR was the main consequence of the VDA treatment. The effect was more drastic at $170^{\circ} \mathrm{C}$ and $190^{\circ} \mathrm{C}$ than at the lower temperatures tested. Increase in the efficiency of hemicellulose removal with temperature in the DA treatment was also observed for triploid poplar (Yang et al., 2017) and corn stover (Lee et al., 2015b), however, the temperature values required for enhanced hemicellulose removal was different due to the different acid concentrations used in those studies. The presence of acid decreased the temperature required for increased solubilization and hemicellulose removal efficiency (Table 1), in accordance with the trend observed for corn stover (Yang and Wyman, 2004). The VDA treatment at $170{ }^{\circ} \mathrm{C}$ for $15 \mathrm{~min}$ increased the cellulose content by $29 \%$ 
Table 1

Composition of the pretreated hazelnut tree pruning residues.

\begin{tabular}{|c|c|c|c|c|c|c|c|c|c|}
\hline Pretreatment & $\begin{array}{l}\mathrm{T} \\
\left({ }^{\circ} \mathrm{C}\right)\end{array}$ & $\begin{array}{l}\mathrm{t} \\
(\min )\end{array}$ & $\begin{array}{l}\text { Solid recovery } \\
(\%)\end{array}$ & $\begin{array}{l}\text { Cellulose } \\
(\%)\end{array}$ & $\begin{array}{l}\text { Cellulose recovery } \\
(\%)\end{array}$ & $\begin{array}{l}\text { Hemicellulose } \\
(\%)\end{array}$ & $\begin{array}{l}\text { Hemicellulose } \\
\text { removal (\%) }\end{array}$ & $\begin{array}{l}\text { Lignin } \\
(\%)\end{array}$ & $\begin{array}{l}\text { Lignin removal } \\
(\%)\end{array}$ \\
\hline Untreated & - & - & 100.0 & 37.2 & - & 20.4 & - & 28.5 & - \\
\hline LHW & 170 & 15 & 86.0 & 40.6 & 93.4 & 13.5 & 43.2 & 33.7 & $-1.7^{\mathrm{a}}$ \\
\hline LHW & 170 & 45 & 75.0 & 48.1 & 94.0 & 10.6 & 61.2 & 41.4 & $-9.0^{\mathrm{a}}$ \\
\hline LHW & 190 & 15 & 73.1 & 51.7 & 92.5 & 5.6 & 79.8 & 43.6 & $-11.7^{\mathrm{a}}$ \\
\hline LHW & 190 & 45 & 66.4 & 51.9 & 84.9 & 2.4 & 92.2 & 50.9 & $-18.6^{\mathrm{a}}$ \\
\hline LHW & 210 & 15 & 65.5 & 50.1 & 87.3 & 0.9 & 97.1 & 49.3 & $-13.3^{\mathrm{a}}$ \\
\hline LHW & 210 & 45 & 64.0 & 51.2 & 85.7 & 0.5 & 98.5 & 49.3 & $-10.7^{\mathrm{a}}$ \\
\hline VDA & 130 & 15 & 84.2 & 46.0 & 104.3 & 14.9 & 38.5 & 34.2 & $-0.9^{\mathrm{a}}$ \\
\hline VDA & 150 & 15 & 79.4 & 48.8 & 104.2 & 12.9 & 49.8 & 39.2 & $-9.2^{\mathrm{a}}$ \\
\hline VDA & 170 & 15 & 67.6 & 52.3 & 95.1 & 5.0 & 83.6 & 41.0 & 2.9 \\
\hline VDA & 190 & 15 & 59.4 & 53.9 & 86.2 & 0.80 & 97.8 & 45.3 & 5.6 \\
\hline Alkali $(0 \%)^{\mathrm{b}}$ & 121 & 60 & 88.8 & 37.1 & 87.9 & 18.0 & 21.6 & 28.7 & 10.7 \\
\hline Alkali $(0.5 \%)^{\mathrm{b}}$ & 121 & 60 & 86.5 & 36.8 & 88.2 & 14.7 & 37.6 & 28.4 & 13.9 \\
\hline Alkali $(2 \%)^{\mathrm{b}}$ & 121 & 60 & 71.3 & 44.2 & 84.8 & 13.2 & 54.0 & 27.7 & 30.7 \\
\hline \multicolumn{10}{|l|}{ Two-stage pretreatment } \\
\hline Primary & \multicolumn{9}{|c|}{ Secondary } \\
\hline \multirow[t]{3}{*}{ LHW $\left(190^{\circ} \mathrm{C}-45 \mathrm{~min}\right)$} & \multicolumn{2}{|c|}{ Alkali $(0 \%)^{\mathrm{b}}$} & 57.8 & 52.5 & 85.4 & 1.5 & 95.8 & 42.2 & 14.4 \\
\hline & \multicolumn{2}{|c|}{ Alkali $(0.5 \%)^{\mathrm{b}}$} & 54.6 & 58.0 & 85.3 & 0.0 & 100.0 & 40.2 & 23.0 \\
\hline & \multicolumn{2}{|c|}{ Alkali $(2 \%)^{\mathrm{b}}$} & 38.9 & 64.0 & 67.1 & 0.0 & 100.0 & 35.7 & 51.2 \\
\hline \multirow[t]{3}{*}{$\operatorname{VDA}\left(170^{\circ} \mathrm{C}-15 \mathrm{~min}\right)$} & \multicolumn{2}{|c|}{ Alkali $(0 \%)^{\mathrm{b}}$} & 64.6 & 50.2 & 87.2 & 3.7 & 88.2 & 36.0 & 18.4 \\
\hline & \multicolumn{2}{|c|}{ Alkali $(0.5 \%)^{\mathrm{b}}$} & 63.3 & 54.0 & 92.0 & 0.0 & 100.0 & 34.2 & 24.1 \\
\hline & \multicolumn{2}{|c|}{ Alkali $(2 \%)^{\mathrm{b}}$} & 42.7 & 67.1 & 77.0 & 0.0 & 100.0 & 29.9 & 55.3 \\
\hline
\end{tabular}

a Negative sign indicates an increase in lignin content with regard to the initial value in the untreated HTPR.

b The $\mathrm{NaOH}$ concentrations used in the alkali treatments are given in parenthesis. All alkali treatments were carried out at $121{ }^{\circ} \mathrm{C}$ for 60 min.

and decreased the hemicellulose content by $63 \%$ as compared to the LHW treatment under the same temperature-time combination. The similar values could be obtained at $190^{\circ} \mathrm{C}$ in the LHW treatment. A small decrease in lignin content was observed in the VDA treatments at $170^{\circ} \mathrm{C}$ and $190^{\circ} \mathrm{C}$, compared to the untreated biomass. In DA pretreatment, the concentration of the acid is generally higher than $0.5 \%$ (w/v) (Girio et al., 2010; Loow et al., 2016). In this study, however, the $\mathrm{H}_{2} \mathrm{SO}_{4}$ concentration was kept at $0.1 \%(\mathrm{w} / \mathrm{v})$, which value was selected to ensure that the $\mathrm{pH}$ of the reaction mixture was around 2 at the start of the VDA treatment. The level of the acid and corresponding $\mathrm{pH}$ value was sufficient to enhance the hemicellulose removal effect at temperatures above $170{ }^{\circ} \mathrm{C}$.

The effect of the alkali treatment was tested by treating the HTPR with $0.5 \%$ and $2 \% \mathrm{NaOH}$ at $121{ }^{\circ} \mathrm{C}$ for $60 \mathrm{~min}$. At this temperature and time combination, even without $\mathrm{NaOH}, 21.6 \%$ of the hemicellulose was removed from the HTPR (Table 1). The solubilized portion of the hemicellulose was composed almost entirely of galactan and arabinan, as concluded from the absence of these carbohydrates in the residual solid and from the xylan remaining almost intact in the solid part. The lignin was removed by $10.7 \%$ under the same condition. In the presence of $0.5 \% \mathrm{NaOH}$, more hemicellulose $(37.6 \%)$ and slightly more lignin (13.9\%) removal were observed (Table 1 ). The $\mathrm{NaOH}$ at a concentration of $2 \%$ was very effective on lignin with a removal level of $30.7 \%$, while it solubilized $54.0 \%$ of the hemicellulose at the same time (Table 1). In previous studies, greater delignification of wheat straw (McIntosh and Vancov, 2011) and cotton stalks (Silverstein et al., 2007) was obtained under similar conditions. Jiang et al. (2016) compared LHW and alkali for giant reed and observed enhanced hemicellulose removal in the LHW and lignin removal in the alkali treatments, in accordance with this study. Some part of the cellulose of the HTPR (12-15\%) was not recovered in the residual solid, although the temperature was low as compared to the LHW and the VDA treatments.

The effectiveness of LHW and VDA in solubilizing hemicellulose and of alkali in removing lignin was combined by conducting two-stage pretreatments. The LHW treatment at $190^{\circ} \mathrm{C}$ for $45 \mathrm{~min}$ and the VDA treatment at $170^{\circ} \mathrm{C}$ for $15 \mathrm{~min}$ were selected as the primary pretreatments, and then in the second stage the pretreated HTPR from the first stage was treated with $0.5 \%$ or $2 \% \mathrm{NaOH}$. In both LHW-alkali and VDAalkali treatments, the hemicellulose removal was complete, and the lignin removal was $23-24 \%$ with $0.5 \% \mathrm{NaOH}$ and over $50 \%$ with $2 \%$ $\mathrm{NaOH}$ (Table 1). One drawback of the two-stage system was that $33 \%$ and $23 \%$ of the cellulose was lost during LHW-alkali and VDA-alkali treatments, respectively when the $\mathrm{NaOH}$ was $2 \%$ in the second stage. Nevertheless, both two-stage pretreatments yielded biomass highly enriched in cellulose (Table 1). Two-stage pretreatment (DA and alkali) approach was also applied by Lee et al. (2015b). The authors reported enhanced xylan and lignin removal and obtained a pretreated solid containing over $80 \%$ glucan. The alkali-acid treatment of sweet sorghum fiber yielded slightly higher cellulose content (59\%) as compared to acid-alkali (reverse sequence) treatment (Li et al., 2016).

\subsection{Enzymatic saccharification of pretreated hazelnut tree pruning residues}

Pretreatments aim to decrease the recalcitrance of the lignocellulosic biomass to enzymatic degradation. In this respect, the effectiveness of the pretreatments applied on the HTPR in this study was tested by saccharification using cellulolytic enzymes. Enzymatic hydrolysis has been generally tested at $2 \%$ solid loadings (Cara et al., 2007; Mussatto et al., 2008), however, in this study comparably higher loading (around 10\%) was used. In all cases, $1 \mathrm{~g}$ of pretreated solid was used, thus the starting cellulose concentrations were different since each treatment yielded different cellulose concentrations in the pretreated solid (Table 1). The release of glucose as a result of cellulose hydrolysis was followed. Preliminary tests revealed that addition of $\beta$ glucosidase did not improve the cellulose hydrolysis. This can be attributed to the presence of substantial $\beta$-glucosidase activity (677 U/ $\mathrm{mL}$ ) in the commercial cellulase preparation (Accelerase 1500) used.

The LHW treated HTPR was subjected to enzymatic hydrolysis at three cellulase levels, namely 15, 30, and $60 \mathrm{FPU} / \mathrm{g}$ biomass. In all cases, untreated biomass used as the control and this yielded a negligible amount of glucose $(<1.6 \mathrm{~g} / \mathrm{L})$ (Fig. 1). Generally, the glucose production was enhanced with increasing pretreatment temperature and time. The enzyme dosage also had a positive effect on the glucose release. In most of the cases, the hydrolysis was completed in $48 \mathrm{~h}$. With cellulase levels of $15 \mathrm{FPU} / \mathrm{g}$ and $30 \mathrm{FPU} / \mathrm{g}, 32-34 \mathrm{~g} / \mathrm{L}$ glucose was obtained in $48 \mathrm{~h}$ from the HTPR treated at $190{ }^{\circ} \mathrm{C}$ for $45 \mathrm{~min}$ and $210{ }^{\circ} \mathrm{C}$ for $45 \mathrm{~min}$ (Fig. 1a and 1b), which corresponded to $55-60 \%$ cellulose conversion. Using the same samples, increasing the cellulase dosage to 

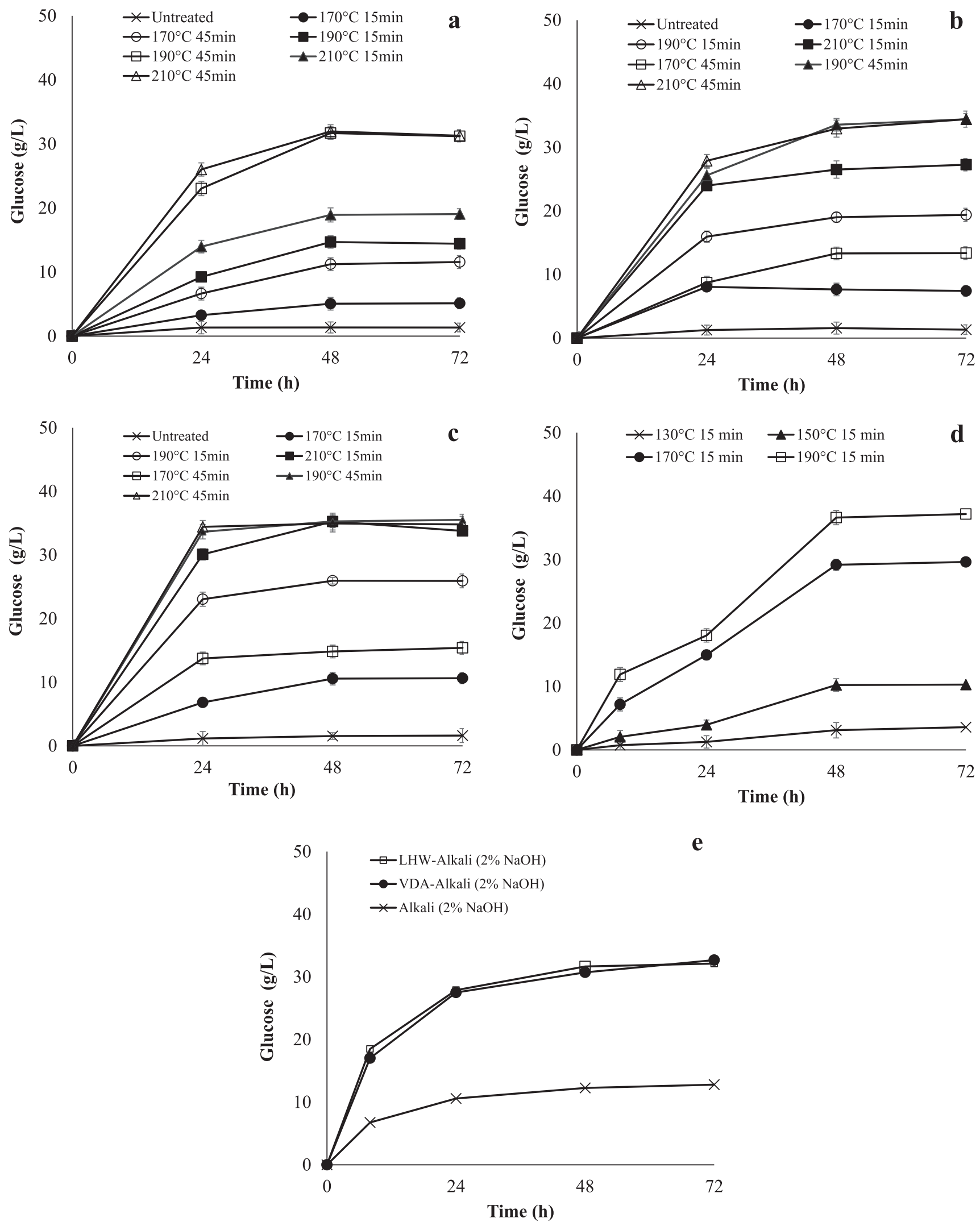

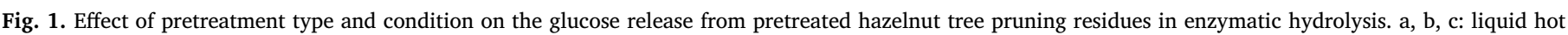

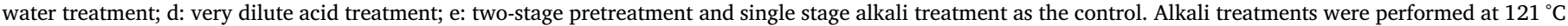
for $60 \mathrm{~min}$ using $2 \% \mathrm{NaOH}$. Cellulase dosage: a: $15 \mathrm{FPU} / \mathrm{g}$; c: $60 \mathrm{FPU} / \mathrm{g}$; b, d, e: $30 \mathrm{FPU} / \mathrm{g}$. 
$60 \mathrm{FPU} / \mathrm{mL}$ increased the glucose level $(35 \mathrm{~g} / \mathrm{L})$ and cellulose conversion (61\%) only slightly but the hydrolysis was faster and completed in $24 \mathrm{~h}$ (Fig. 1c). The high cellulase level allowed the HTPR treated at $210^{\circ} \mathrm{C}$ for $15 \mathrm{~min}$ to yield a high amount of glucose and high cellulose conversion as well. In the 15 min treatments, cellulose conversion increased linearly with temperature at all cellulase levels. In the $45 \mathrm{~min}$ treatments, on the other hand, the conversions were similar at $190{ }^{\circ} \mathrm{C}$ and $210{ }^{\circ} \mathrm{C}$ and considerably higher compared to one obtained at $170{ }^{\circ} \mathrm{C}$. The cellulose conversion values were in accordance with the ones obtained with LHW treated olive tree prunings (66\%) (Cara et al., 2007) and giant reed (around 60\%) (Jiang et al., 2016), whereas higher values were reported for wheat straw (Pérez et al., 2008) and sugarcane bagasse (Yu et al., 2013). Although the samples treated at $190{ }^{\circ} \mathrm{C}$ and $210^{\circ} \mathrm{C}$ for $45 \mathrm{~min}$, and $210^{\circ} \mathrm{C}$ for $15 \mathrm{~min}$ had similar compositions, the glucose released from the last one was less than the others at low cellulase dosage. This effect can be related to the influence of the treatments on the lignin remaining in the solid. Treatments under certain conditions may have decreased the unproductive binding of the enzyme to lignin, as a result of possible disruption of the lignin structure (Kumar et al., 2012). Otherwise, higher enzyme dosage was required for substantial glucose release, as was observed for HTPR treated at $210^{\circ} \mathrm{C}$ for $15 \mathrm{~min}$.

The VDA treated HTPR was hydrolyzed using $30 \mathrm{FPU} / \mathrm{g}$ biomass cellulase. The general trend was similar to the case observed with LHW treated HTPR, except that comparably less glucose was released in $24 \mathrm{~h}$. The treatment temperature had a drastic effect on the hydrolysis (Fig. 1d). The treatments at $130{ }^{\circ} \mathrm{C}$ and $150{ }^{\circ} \mathrm{C}$ yielded a very low amount of glucose, while a notable increase was observed with the HTPR treated at $170{ }^{\circ} \mathrm{C}$. Increasing the temperature further to $190{ }^{\circ} \mathrm{C}$ increased the glucose production to $36.6 \mathrm{~g} / \mathrm{L}$, corresponding to a cellulose conversion of $61 \%$. The higher hydrolysis efficiency with the samples treated at $170{ }^{\circ} \mathrm{C}$ and $190^{\circ} \mathrm{C}$ was in parallel to the enhanced hemicellulose removal at these temperatures (Table 1). Compared to the LHW treatment at $190{ }^{\circ} \mathrm{C}$ for $15 \mathrm{~min}$, the acid catalysis enhanced the glucose production and cellulose conversion significantly under the same condition (Fig. 1b and d). The difference was more drastic between the samples treated at $170{ }^{\circ} \mathrm{C}$. This was also in accordance with the hemicellulose contents of the pretreated HTPR.

The cellulose conversion increased almost linearly with the decreasing hemicellulose content of the HTPR treated either with LHW or VDA (Fig. 2). This indicated the barrier effect of hemicellulose on the enzymatic hydrolysis. The similar linear relation between the xylan removal and the cellulose conversion was reported for LHW treated biomass, such as sugarcane bagasse (Lv et al., 2013) and soybean straw

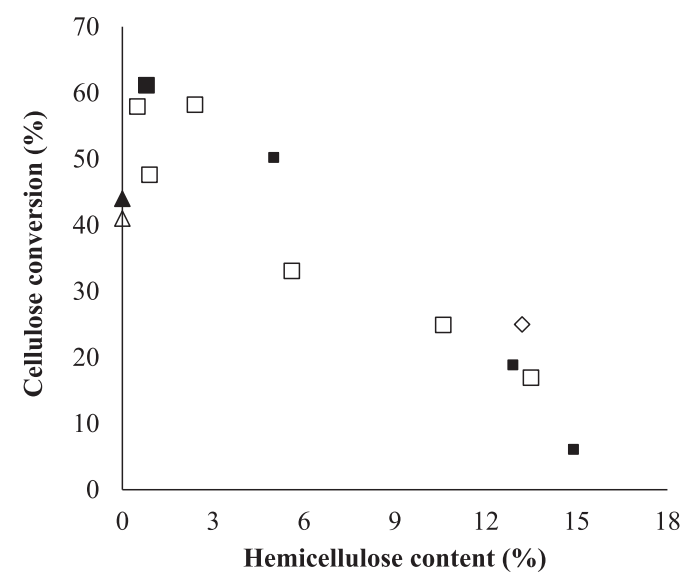

Fig. 2. Effect of hemicellulose concentration in the treated hazelnut tree pruning residue on the fraction of cellulose that was converted to glucose in enzymatic hydrolysis. Treatments: Liquid hot water $(\square)$; Very dilute acid ( $\square$ ); Alkali $(2 \% \mathrm{NaOH})(\diamond)$; Liquid hot water-Alkali $(\mathbf{\Delta})$; Very dilute acid-Alkali $(\triangle)$.
(Wan et al., 2011). Mussatto et al. (2008) observed enhanced enzymatic hydrolysis of acid treated brewer's spent grain, which had lower hemicellulose, but higher lignin content compared to the raw material. It should be noted that lignin content of the treated HTPR samples was inversely related to hemicellulose content. Thus, there was no apparent negative effect of increased lignin concentration or lignin to cellulose ratio on the cellulose conversion in the enzymatic hydrolysis following LHW and VDA treatments. Lv et al. (2013) also reported that cellulose conversion was independent of lignin content of the LHW treated sugarcane bagasse.

The LHW and VDA treated HTPR that were then treated with $2 \%$ $\mathrm{NaOH}$ were subjected to enzymatic hydrolysis with $30 \mathrm{FPU} / \mathrm{g}$ biomass cellulase. The alkali treatment using $0.5 \% \mathrm{NaOH}$ as the second stage was omitted in enzymatic hydrolysis test due to its relatively poorer efficiency on lignin removal. Both LHW-alkali and VDA-alkali pretreatments resulted in same hydrolysis kinetics (Fig. 1e). Approximately, $31 \mathrm{~g} / \mathrm{L}$ glucose was produced in $48 \mathrm{~h}$, while the level was only slightly lower after the first $24 \mathrm{~h}$. Although the glucose levels were comparable, the maximum cellulose conversion $(44.5 \%)$ was lower than the ones obtained in the previous cases. This was due to the higher cellulose contents of the two-stage pretreated biomass. In spite of the lower hemicellulose and lignin concentrations and lignin to cellulose ratio in HTPR after the pretreatments, the glucose released could not be enhanced. This could be attributed to a possible inhibition exerted by the glucose on the activity of cellulase in the hydrolysis medium (Andric et al., 2010). In enzymatic treatments following single or twostage pretreatments, the maximum glucose levels attained were between 32.7 and $36.6 \mathrm{~g} / \mathrm{L}$ and the production stopped although the cellulose was not depleted. Cara et al. (2006) observed similar inhibition of enzymatic hydrolysis of olive tree pruning treated with steam explosion and alkaline peroxide. The authors related that to the high biomass loading (10\%) and observed higher cellulose conversion when the biomass loading was decreased to $2 \%$. It should also be noted that at high solid loadings diffusional limitations due to the inadequate mixing could influence the saccharification negatively (Modenbach and Nokes, 2013). In the enzymatic saccharification of HTPR from two-stage treatments, the effect of hemicellulose concentration on cellulose conversion was different, i.e. conversion values were lower than that could be expected regarding the trends observed for single stage treatments (Fig. 2).

The HTPR treated only with alkali $(2 \% \mathrm{NaOH})$ was also tested for hydrolysis (Fig. 1e). This sample yielded notably lower glucose (12.3 g/ L) than the two-stage pretreated samples. The HTPR from other alkali treatments were not tested for glucose production due to the poor cellulose conversion obtained with $2 \% \mathrm{NaOH}$ treatment. The lignin content of the $2 \% \mathrm{NaOH}$ treated HTPR was low $(27.7 \%)$, however, it contained a significantly higher amount of hemicellulose (13.2\%). Considering the absence of hemicellulose in the two-stage pretreated samples, the low hydrolysis efficiency could be linked to the hemicellulose as discussed above. The effect of the hemicellulose concentration of the alkali treated HTPR on the cellulose conversion value was in accordance with the trend observed for LHW and VDA treated HTPR (Fig. 2).

The global yield values obtained in saccharification of pretreated HTPR using 30 FPU/g cellulase were shown in Fig. 3. In LHW and VDA treatments, the yields increased significantly with either the treatment temperature or time, except that the yield value obtained in LHW treatment at $210{ }^{\circ} \mathrm{C}$ for 45 min was slightly less than the one obtained at $190{ }^{\circ} \mathrm{C}$ for $45 \mathrm{~min}$. The latter condition provided the highest glucose yield among all pretreatments tested in this study. Under this condition, $21 \%$ of the raw HTPR could be obtained as glucose, on a dry weight basis. The yields obtained in VDA treatments at $170{ }^{\circ} \mathrm{C}$ and $190{ }^{\circ} \mathrm{C}$ for 15 min were comparable to the LHW treatments at higher severity $\left(190{ }^{\circ} \mathrm{C}-45 \mathrm{~min}\right.$ and $\left.210^{\circ} \mathrm{C}-45 \mathrm{~min}\right)$. The HTPR subjected to two-stage pretreatments had high cellulose concentration whereas cellulose loss was considerable (Table 1) and cellulose conversion was comparably 


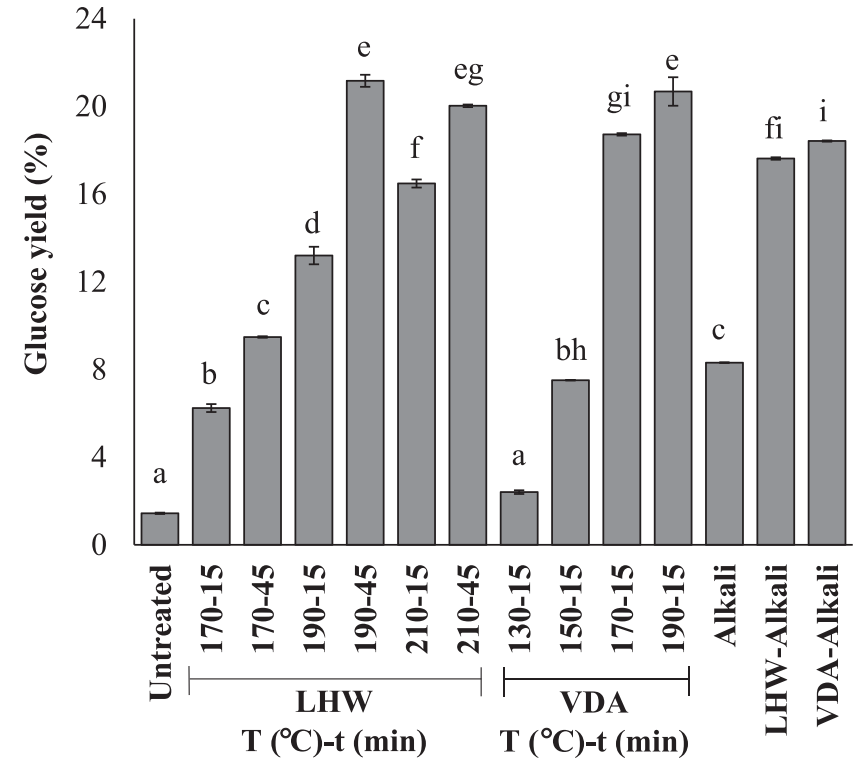

Fig. 3. Overall glucose yields (\% of raw HTPR) from enzymatic ( $30 \mathrm{FPU} / \mathrm{g}$ cellulase) saccharification of HTPR treated with liquid hot water (LHW), very dilute acid (VDA), alkali, LHW $\left(190^{\circ} \mathrm{C}-45 \mathrm{~min}\right)$-Alkali and VDA $\left(170{ }^{\circ} \mathrm{C}-15 \mathrm{~min}\right)$-Alkali treatments. Alkali treatments were carried out at $121{ }^{\circ} \mathrm{C}$ for $60 \mathrm{~min}$ using $2 \% \mathrm{NaOH}$. Different letters indicate statistically significant difference ( $p<0.05$, one-way ANOVA and Tukey-Kramer test).

lower. These resulted in slightly lower glucose yield compared to maximum values obtained with LHW and VDA treated HTPR (Fig. 3).

\section{Conclusion}

HTPR was evaluated for the first time for its potential as a source of glucose. The hemicellulose in the HTPR was shown to be the main barrier against the enzymatic digestibility of cellulose. LHW effectively removed the hemicellulose and allowed the conversion of cellulose. The inclusion of the small amount of acid (VDA treatment) decreased the temperature required for hemicellulose removal. The partial delignification of the pretreated HTPR using alkali as the secondary treatment did not improve the cellulose conversion or the glucose yield. Incomplete cellulose conversion in all cases indicated a possible inhibitory effect of glucose on the cellulase.

\section{References}

Adney, B., Baker, J., 2008. Measurement of cellulase activities. National Renewable Energy Laboratory, NREL/TP-510-42628.

Alvarez, C., Reyes-Sosa, F.M., Diez, B., 2016. Enzymatic hydrolysis of biomass from wood. Microb. Biotechnol. 9 (2), 149-156.

Alvira, P., Tomas-Pejo, E., Ballesteros, M., Negro, M.J., 2010. Pretreatment technologies for an efficient bioethanol production process based on enzymatic hydrolysis: a review. Bioresour. Technol. 101 (13), 4851-4861.

Andric, P., Meyer, A.S., Jensen, P.A., Dam-Johansen, K., 2010. Effect and modeling of glucose inhibition and in situ glucose removal during enzymatic hydrolysis of pretreated wheat straw. Appl. Biochem. Biotechnol. 160 (1), 280-297.

Bascetincelik, A., Ozturk, H., Karaca, C., Kacira, M., Ekinci, K., Kaya, D., Banan, A., Gunes, K., Komitti, N., Barnes, I., 2006. Guide on exploitation of agricultural residues in Turkey. University of Çukurova. LIFE03TCY/TR/000061.

Colantoni, A., Delafanti, L.M., Longo, L., Evic, N., Gallucci, F., 2015. Use of hazelnut's pruning to produce biochar by gasifier small scale plant. Int. J. Renew. Energy Res. 5 (3), 873-878.

Cara, C., Moya, M., Ballesteros, I., Negro, M.J., González, A., Ruiz, E., 2007. Influence of solid loading on enzymatic hydrolysis of steam exploded or liquid hot water pretreated olive tree biomass. Process Biochem. 42 (6), 1003-1009.

Cara, C., Ruiz, E., Ballesteros, I., Negro, M.J., Castro, E., 2006. Enhanced enzymatic hydrolysis of olive tree wood by steam explosion and alkaline peroxide delignification. Process Biochem. 41 (2), 423-429.

Carvalheiro, F., 2004. Production of oligosaccharides by autohydrolysis of brewery's spent grain. Bioresour. Technol. 91 (1), 93-100.

Çöpür, Y., Tozluoglu, A., Özkan, M., 2013. Evaluating pretreatment techniques for converting hazelnut husks to bioethanol. Bioresour. Technol. 129, 182-190.

Esposito, T., Sansone, F., Franceschelli, S., Del Gaudio, P., Picerno, P., Aquino, R.P.,

Mencherini, T., 2017. Hazelnut (Corylus avellana L.) shells extract: phenolic compo-

sition, antioxidant effect and cytotoxic activity on human cancer cell lines. Int. J. Mol. Sci. 18 (2), 392.

FAOSTAT, 2016. http://www.fao.org/faostat/en/\#data/QC (Last accessed Feb 5, 2018)

Fiorentino, G., Ripa, M., Ulgiati, S., 2017. Chemicals from biomass: technological versus environmental feasibility. A review. Biofuels Bioprod. Biorefin. 11 (1), 195-214.

Girio, F.M., Fonseca, C., Carvalheiro, F., Duarte, L.C., Marques, S., Bogel-Lukasik, R., 2010. Hemicelluloses for fuel ethanol: a review. Bioresour. Technol. 101 (13), 4775-4800.

Grover, A.K., MacMurchie, D.D., Cushley, R.J., 1977. Studies on almond emulsin $\beta d-$ glucosidase I. Isolation and characterization of a bifunctional isozyme. Biochim. Biophys. Acta Enzymol. 482 (1), 98-108.

Heitz, M., Carrasco, F., Rubio, M., Chauvette, G., Chornet, E., Jaulin, L., Overend, R.P., 1986. Generalized correlations for the aqueous liquefaction of lignocellulosics. Can. J. Chem. Eng. 64, 647-650.

Hu, F., Ragauskas, A., 2014. Suppression of pseudo-lignin formation under dilute acid pretreatment conditions. RSC Adv. 4 (9), 4317-4323.

Jesus, M.S., Romaní, A., Genisheva, Z., Teixeira, J.A., Domingues, L., 2017. Integral valorization of vine pruning residue by sequential autohydrolysis stages. J. Clean. Prod. 168, 74-86.

Jiang, D., Ge, X., Zhang, Q., Li, Y., 2016. Comparison of liquid hot water and alkaline pretreatments of giant reed for improved enzymatic digestibility and biogas energy production. Bioresour. Technol. 216, 60-68.

Jonsson, L.J., Martin, C., 2016. Pretreatment of lignocellulose: formation of inhibitory byproducts and strategies for minimizing their effects. Bioresour. Technol. 199, $103-112$.

Kim, J.S., Lee, Y., Kim, T.H., 2016. A review on alkaline pretreatment technology for bioconversion of lignocellulosic biomass. Bioresour. Technol. 199, 42-48.

Kumar, L., Arantes, V., Chandra, R., Saddler, J., 2012. The lignin present in steam pretreated softwood binds enzymes and limits cellulose accessibility. Bioresour. Technol. 103 (1), 201-208.

Laser, M., Schulman, D., Allen, S.G., Lichwa, J., Antal Jr, M.J., Lynd, L.R., 2002. A comparison of liquid hot water and steam pretreatments of sugar cane bagasse for bioconversion to ethanol. Bioresour. Technol. 81 (1), 33-44.

Lee, C., Zheng, Y., VanderGheynst, J.S., 2015a. Effects of pretreatment conditions and post-pretreatment washing on ethanol production from dilute acid pretreated rice straw. Biosys. Eng. 137, 36-42.

Lee, J.W., Kim, J.Y., Jang, H.M., Lee, M.W., Park, J.M., 2015b. Sequential dilute acid and alkali pretreatment of corn stover: sugar recovery efficiency and structural characterization. Bioresour. Technol. 182, 296-301.

Li, P., Cai, D., Zhang, C., Li, S., Qin, P., Chen, C., Wang, Y., Wang, Z., 2016. Comparison of two-stage acid-alkali and alkali-acid pretreatments on enzymatic saccharification ability of the sweet sorghum fiber and their physicochemical characterizations. Bioresour. Technol. 221, 636-644.

Loow, Y.-L., Wu, T.Y., Md. Jahim, J., Mohammad, A.W., Teoh, W.H., 2016. Typical conversion of lignocellulosic biomass into reducing sugars using dilute acid hydrolysis and alkaline pretreatment. Cellulose 23 (3), 1491-1520.

Lv, S., Yu, Q., Zhuang, X., Yuan, Z., Wang, W., Wang, Q., Qi, W., Tan, X., 2013. The influence of hemicellulose and lignin removal on the enzymatic digestibility from sugarcane bagasse. Bioenergy Res. 6 (4), 1128-1134.

Ma, X., Yang, X., Zheng, X., Chen, L., Huang, L., Cao, S., Akinosho, H., 2015. Toward a further understanding of hydrothermally pretreated holocellulose and isolated pseudo lignin. Cellulose 22 (3), 1687-1696.

McIntosh, S., Vancov, T., 2011. Optimisation of dilute alkaline pretreatment for enzymatic saccharification of wheat straw. Biomass Bioenergy 35 (7), 3094-3103.

Modenbach, A.A., Nokes, S.E., 2013. Enzymatic hydrolysis of biomass at high-solids loadings - a review. Biomass Bioenergy 56, 526-544.

Monlau, F., Barakat, A., Steyer, J.P., Carrere, H., 2012. Comparison of seven types of thermo-chemical pretreatments on the structural features and anaerobic digestion of sunflower stalks. Bioresour. Technol. 120, 241-247.

Mosier, N., Wyman, C., Dale, B., Elander, R., Lee, Y.Y., Holtzapple, M., Ladisch, M., 2005. Features of promising technologies for pretreatment of lignocellulosic biomass. Bioresour. Technol. 96 (6), 673-686.

Mussatto, S.I., Fernandes, M., Milagres, A.M.F., Roberto, I.C., 2008. Effect of hemicellulose and lignin on enzymatic hydrolysis of cellulose from brewer's spent grain. Enzyme Microb. Technol. 43 (2), 124-129.

Pérez, J.A., Ballesteros, I., Ballesteros, M., Sáez, F., Negro, M.J., Manzanares, P., 2008 Optimizing Liquid Hot Water pretreatment conditions to enhance sugar recovery from wheat straw for fuel-ethanol production. Fuel 87 (17-18), 3640-3647.

Selig, M.J., Vinzant, T.B., Himmel, M.E., Decker, S.R., 2009. The effect of lignin removal by alkaline peroxide pretreatment on the susceptibility of corn stover to purified cellulolytic and xylanolytic enzymes. Appl. Biochem. Biotechnol. 155 (1-3), 397-406.

Shahidi, F., Alasalvar, C., Liyana-Pathirana, C.M., 2007. Antioxidant phytochemicals in hazelnut kernel (Corylus avellana L.) and hazelnut byproducts. J. Agric. Food Chem. 55 (4), 1212-1220.

Silverstein, R.A., Chen, Y., Sharma-Shivappa, R.R., Boyette, M.D., Osborne, J., 2007. A comparison of chemical pretreatment methods for improving saccharification of cotton stalks. Bioresour. Technol. 98 (16), 3000-3011.

Sluiter, A., Hames, B., Ruiz, R., Scarlata, C., Sluiter, J., Templeton, D., D, C., 2011. Determination of structural carbohydrates and lignin in biomass. National Renewable Energy Laboratory. NREL/TP-510-42618.

Sun, Y., Cheng, J., 2002. Hydrolysis of lignocellulosic materials for ethanol production: a review. Bioresour. Technol. 83 (1), 1-11. 
Surek, E., Buyukkileci, A.O., 2018. Extraction of antioxidant compounds from hazelnut wastes using subcritical water. J. Food 43 (2), 211-221.

Surek, E., Buyukkileci, A.O., 2017. Production of xylooligosaccharides by autohydrolysis of hazelnut (Corylus avellana L.) shell. Carbohydr. Polym. 174, 565-571.

Taherzadeh, M.J., Karimi, K., 2008. Pretreatment of lignocellulosic wastes to improve ethanol and biogas production: a review. Int. J. Mol. Sci. 9 (9), 1621-1651.

Wan, C., Zhou, Y., Li, Y., 2011. Liquid hot water and alkaline pretreatment of soybean straw for improving cellulose digestibility. Bioresour. Technol. 102 (10), 6254-6259.

Yang, B., Wyman, C.E., 2004. Effect of xylan and lignin removal by batch and flowthrough pretreatment on the enzymatic digestibility of corn stover cellulose. Biotechnol. Bioeng. 86 (1), 88-95.

Yang, J., Kim, J.E., Kim, H.E., Yu, J.-H., Cha, Y.-L., Kim, K.H., 2017. Enhanced enzymatic hydrolysis of hydrothermally pretreated empty fruit bunches at high solids loadings by the synergism of hemicellulase and polyethylene glycol. Process Biochem. 58, 211-216.

Yu, Q., Zhuang, X., Lv, S., He, M., Zhang, Y., Yuan, Z., Qi, W., Wang, Q., Wang, W., Tan, X., 2013. Liquid hot water pretreatment of sugarcane bagasse and its comparison with chemical pretreatment methods for the sugar recovery and structural changes. Bioresour. Technol. 129, 592-598.

Zabed, H., Sahu, J.N., Boyce, A.N., Faruq, G., 2016. Fuel ethanol production from lignocellulosic biomass: an overview on feedstocks and technological approaches. Renew. Sust. Energy. Rev. 66, 751-774.

Zheng, Y., Pan, Z., Zhang, R., Wang, D., 2009. Enzymatic saccharification of dilute acid pretreated saline crops for fermentable sugar production. Appl. Energy. 86 (11), 2459-2465. 